\title{
Opportunities and Challenges for Straw Fortification for Livestock Feed: Scope for Mechanization
}

\author{
D.J. Shrinivasa ${ }^{1 *}$ and Devanand Maski ${ }^{2}$ \\ ${ }^{1}$ Department of FMPE, CTAE, MPUAT, Udaipur, Rajasthan, India \\ ${ }^{2}$ Department of FMPE, CAE, UAS, Raichur, Karnataka, India \\ *Corresponding author
}

\section{Keywords}

Baling, Fortification methods, Straw fortification, Livestock feed.

Article Info

Accepted: 19 July 2017 Available Online: 10 September 2017

\section{A B S T R A C T}

The prime reason for the poor performance of livestock in developing countries like India is the seasonal inadequacy of feed, both in terms of quantity and quality. Livestock production is mainly based on use of agriculture by-products and crop residues (including straws, stovers, husks and other crop by-products make up a major portion of animal feed in many developing countries) as feed resource. These residues are low quality fodder with low nitrogen, high lignin contents, poor digestibility and low intake by the animals. The fortification of straw upgrades the nutritional value of poor quality roughage. There are two types of (viz., loose and baled) straw fortification methods being practice in India. In these methods, the straw fortification will be performed in two different steps and in offfield condition. These reasons are leading to make the above methods more time consuming and labour intensive process. Therefore, there is a need to develop and adopt a suitable fortification application system which perform fortification job while baling the straw in the field itself so that, simultaneous fortification cum baling of straw in in-field condition is possible. So that, in addition to improve the nutritional value of straw, it also helps to reduce the time of fortification and labour expenses which will play an important role in traditional fortification methods.

\section{Introduction}

Feed and fodder scarcity has been one of the limiting factors for improvement of livestock productivity in India (Thakur et al., 2007). Dairy production is mainly based on use of agricultural by-products and crop residues such as cereal straws contributing $45-60 \%$ of the feed resource consumed by dairy animals. There is regional variation in the type of cereal straw commonly used for feeding animals. In Northern India, wheat straw is commonly used, while feeding paddy straw is common in Eastern, Southern and most parts of Western region (Roy and
Rangnekar, 2006). The fundamental reason for the lower performance of livestock in developing countries is the seasonal inadequacy of feed, both in terms of quantity and quality. These deficiencies have rarely been corrected by conservation and/or supplementation, often for lack of infrastructure, technical know-how, poor management etc. (Makkar, 2000). The agricultural residues are low quality fodder (including straws, stovers, husks and other crop by-products make up a major portion of animal feed in many developing countries) 
with low nitrogen and high lignin contents. These two factors are responsible for dairy animal's poor digestibility and low intake and consequently low productivity of livestock (Maeng and Chung, 1989; Smith, 2001; Thakur et al., 2007). Expensive concentrates and milling by-products are forcing farmers to rely more upon crop residues as source of energy. India contributes nearly $17 \%$ of the world's human population and has a share of about $10.7 \%$ of total livestock resource. But it has only $2.3 \%$ of the total land area in the world. As per the $19^{\text {th }}$ livestock census, India's livestock population was 512.05 million during 2012-13. It was estimated that, the shortfall of dry fodder is $163 \mathrm{Mt}$ (million tonnes) and the inadequacy of green fodder is 79 Mt. This shortage of fodder is due to growing importance of food crops and other cash crops to meet the needed of the growing human population (Anon., 2013; Anon., 2015).

Rice straw and other such crop residues including grass (from uncultivated land) have rich in cell wall lignin and provide unbalanced nutrients for the growth of rumen microbes (Sultana et al., 2011). The rice and wheat straws are the main crop residues which farmers usually store and use them as ruminant feed in India, especially during the long dry season whereby natural forages are being in constraint. The rice straw contains protein (2 to $5 \%$ ), crude fibre (34\%) and lignin contents (NDF > $50 \%$ ) and low digestibility (<60\%) (Wanapat et al., 2013). Fibre contains high energy but is not available to animals due to its highly indigestible in nature. The primary components of fibre are cellulose, hemicellulose and lignin (Hussein et al., 2010).

\section{Importance of straw fortification}

Cereal straws are characterized by low crude protein, high lignin and low available energy content resulting in low intakes and utilisation by the livestock. Therefore the mechanical and chemical methods of processing have been proposed for upgrading the nutritional value of poor quality roughages (Hadjipanayiotu et al., 1997).

Physical and/or chemical treatments are necessary to improve the nutrient utilisation as well as to increase the bulk density to minimise the cost of collection, handling, transportation and storage. Since rice, wheat and other straws have low nutritive value, some fortification ingradient are mixed with them to increase the milk production of livestock. Molasses is one such fortification ingradient that increases the palatability of the straws due to its high sugar content. It also acts as a binder for the densification of straw (Garg et al., 2005). Ammonia is another such ingradient, treatment of crop residues with ammonia can increase digestibility of dry matter by 20 to $40 \%$, crude protein content by 2 to 3 fold and increase voluntary consumption by 20 to $35 \%$ (Maeng and Chung, 1989). Use of a cheap source of nitrogen such as urea to improve the nitrogen and makes it a technically feasible method to improve the nutritive value of straw. But its application in the field has been very limited in India.

The fortification of straw from lime can also improve the utilization of straw by the livestock and supplement the ration with calcium, which has been found to be in a negative balance in cattle feed like rice straw (Hanafi et al., 2012). The acid detergent and neutral detergent fibre content of high moisture hay will be reduced by treating it with urea and that will increases the digestibility of their fibre components (Alhadhrami, 1991). Crude protein (CP) content of rice straw treated with 3 and $5 \%$ urea will increase from 2.90 to 5.90 and 6.70 $\%$ respectively (Saadullah et al., 1981). 
Ammoniation of wheat straw with urea significantly improves the mean daily consumption of wheat straw by $46 \%$ (Cloete and Kritzinger, 1984). The addition of urea at a rate of $40 \mathrm{~g} \mathrm{~kg}^{-1}$ of forage and above (weight w.b.) reduces microbial activity and increases the nitrogen content of hay by approximately $14.50 \mathrm{~g} \mathrm{~kg}^{-1}$ (Belanger et al., 1987). Maeng and Chung (1989) reported the daily gain of 20 and $30 \%$ respectively for animals fed by anhydrous and aqueous ammonia treated rice straw.

Addition of anhydrous ammonia into the high-density round bales of rice straw improves palatability to cattle and conditions of straw to withstand for long periods of outside storage (Toenjes et al., 1986). Fertilizer-grade urea treated high moisture alfalfa hay remains free of visible mould and increases the nutritive value of the hay because urea will broke down to ammonia and carbon-dioxide. The released ammonia acts as a preservative (Ghate and Bilanski, 1979). The voluntary feed intake is also significantly higher on urea treated rice straw rations stored either as stack or bale compared to untreated rice straw ration stored either as stack or bale (Prasad et al., 1998). The lactating goats feeding by urea-treated wheat straw would significantly increases the percentage of fat, solid not fat, casein, titrable acidity, ash and decreases $\mathrm{pH}$ of milk compared to those feeding with wheat straw alone (Al-Busadah, 2008).

\section{Straw fortification by various treatment}

Various treatment methods are being used to improve the nutritive value of rice straw those include physical, biological and chemical treatment. Among these methods chemical, physical and/or combination of physicalchemical methods of straw fortification is being widely practiced as a method of improving intake and digestibility.

\section{Physical treatment methods}

In this method, crop residues can be ground, soaked, pelleted or chopped to reduce particle size or can treated with steam and/ pressure (Hanafi et al., 2012). These methods improve the quality of cellulosic feedstuffs for animals by freeing digestible materials from lignin or silica (Liu et al., 1990). But these treatments are not practical for use on small scale farms because they require machines or industrial processing.

\section{Biological treatment methods}

The use of fungi and/or their enzymes that metabolize lignocelluloses is a potential biological treatment to improve the nutritional value of straw by selective delignification (Hanafi et al., 2012). The potential of biological treatment would be explained by the ability of certain microbes specifically basidomycetes fungi to disrupt plant cell by partial breakdown of the lignin-carbohydrate complex thus improving their utilisation in the rumen by increasing the availability of fermentable energy to rumen microbes (Mahesh and Mohini, 2013). Nitrogen intake, its digestion and retention in cross breed calves fed by fungal treated wheat straw would higher than urea treated straw fed group (Walli et al., 1988).

\section{Chemical treatment methods}

In this method, chemicals are used to improve the utilization of crop residues by ruminants by improving their feeding value. The chemicals may be alkaline, acidic or oxidative agents. Among these, alkali agents have been most widely investigated and practically accepted for application on farms. Basically, these alkali agents can be absorbed into the cell wall and chemically break down the ester bonds between lignin and hemicellulose and cellulose and physically make the structural 
fibres swollen. The most commonly used alkaline agents are sodium hydroxide $(\mathrm{NaOH})$, ammonia $\left(\mathrm{NH}_{3}\right)$, lime and urea (Hanafi et al., 2012).

Among the chemicals being used for straw fortification, $\mathrm{NH}_{3}$ and urea have a considerable attention because these chemicals make the treated material palatable by solubilizing the hemicellulose fractions, thus improving the DM digestibility and daily

Fig.1 Schematic flow chart of loose straw fortification method

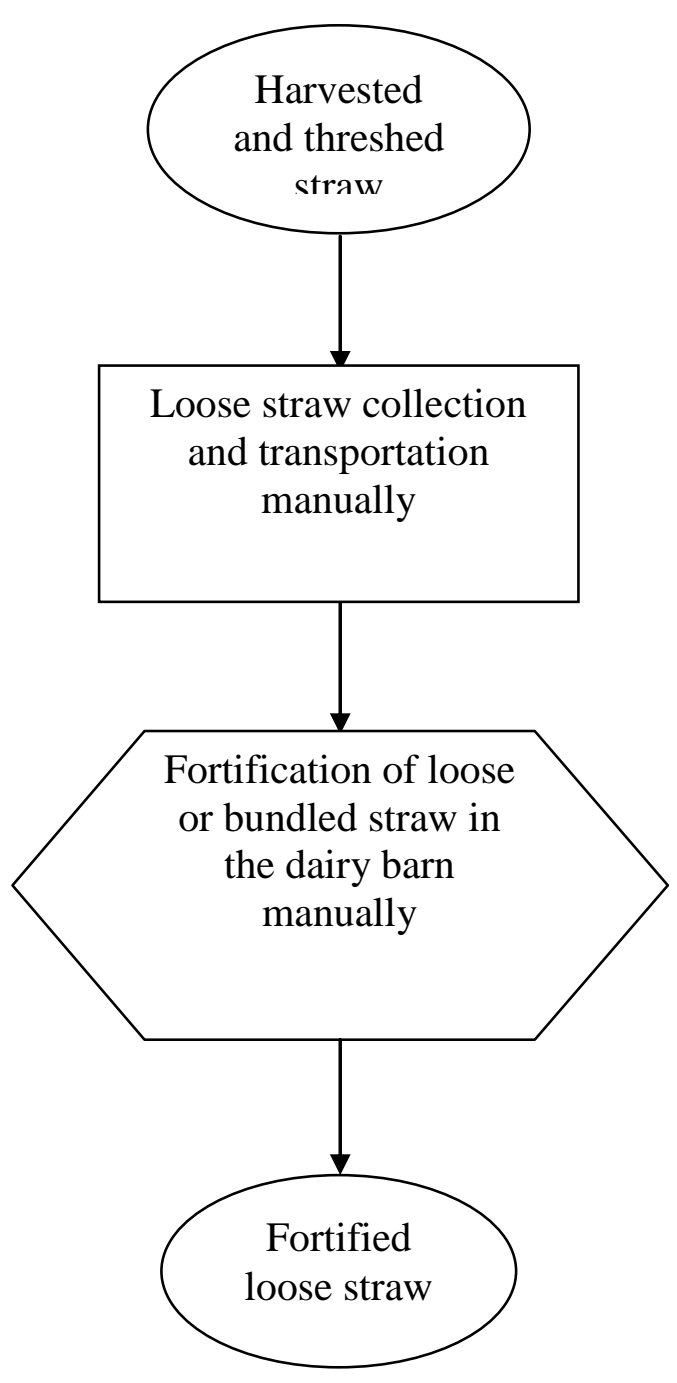

DM intake (Mir et al., 1991, Jabbaret al., 2009 and Ali et al., 2012). In India, use of urea for straw fortification is common because of its readily availability, safe and easy to handle as it is soluble in water.

Efforts were made in the past to improve the straw digestibility and protein through chemical treatment. The various fortification chemicals used by several researchers in past studies are given in table 1 .

Fig.2 Schematic flow chart of baled straw fortification method

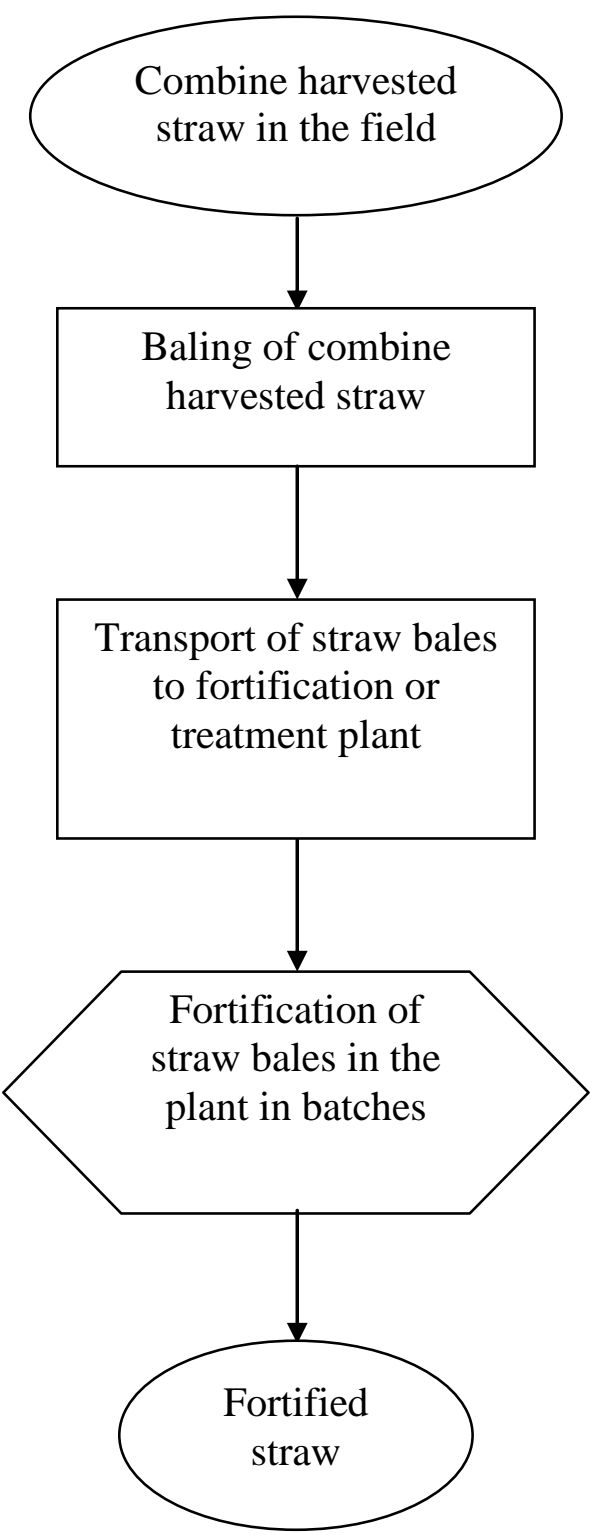


Fig.3 Various loose straw fortification methods (a indicates straw chopped to small pieces for fortification, $\mathrm{b}$ and $\mathrm{c}$ shows non chopped loose straw fortification and $\mathrm{d}$ represents fortification by spraying and stacking of bundled straw layer by layer)

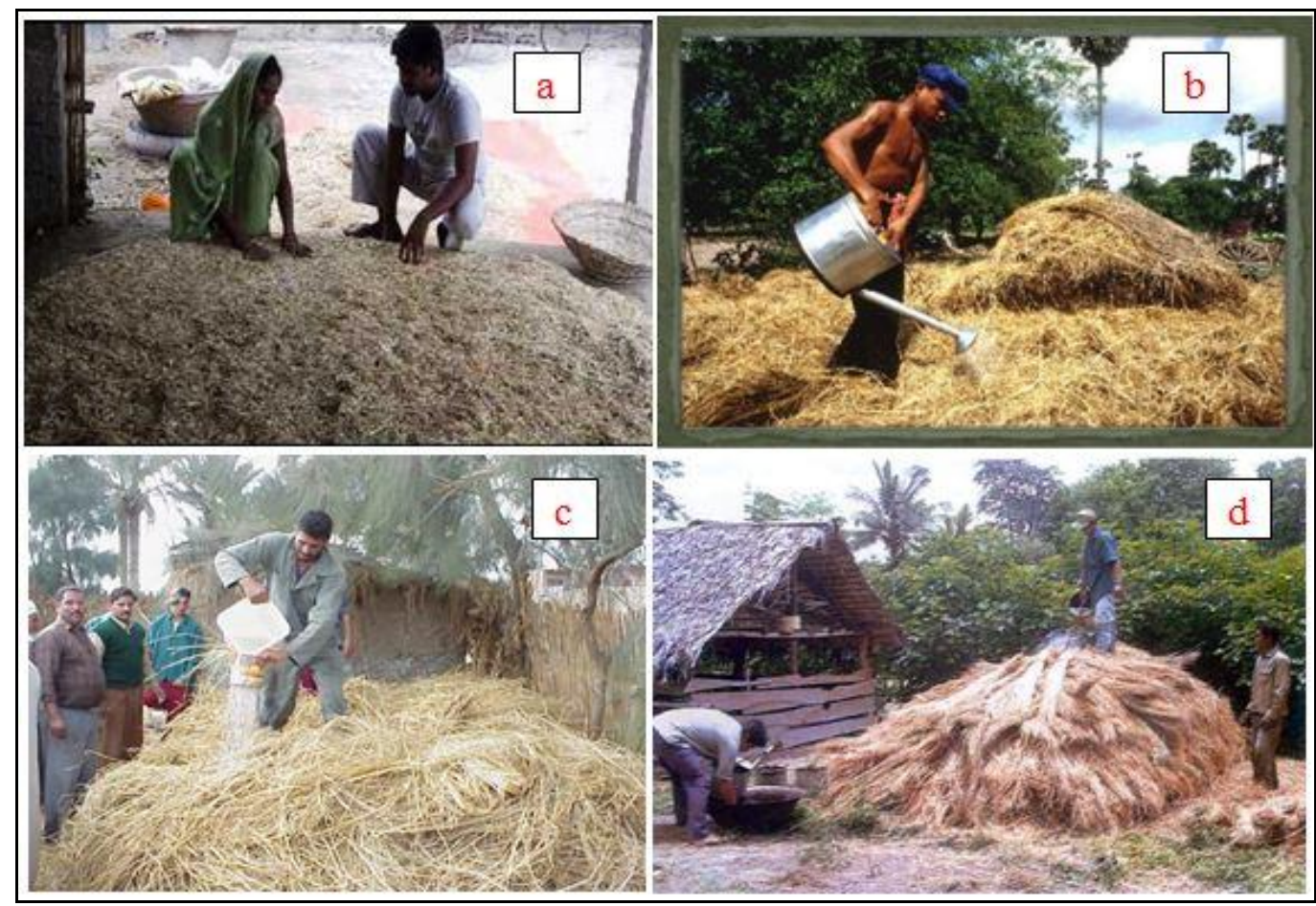

Fig.4 Fortification of baled straw in treatment plant (a and c and b and d represents the straw bales in batch type treatment plant before and after fortification respectively)

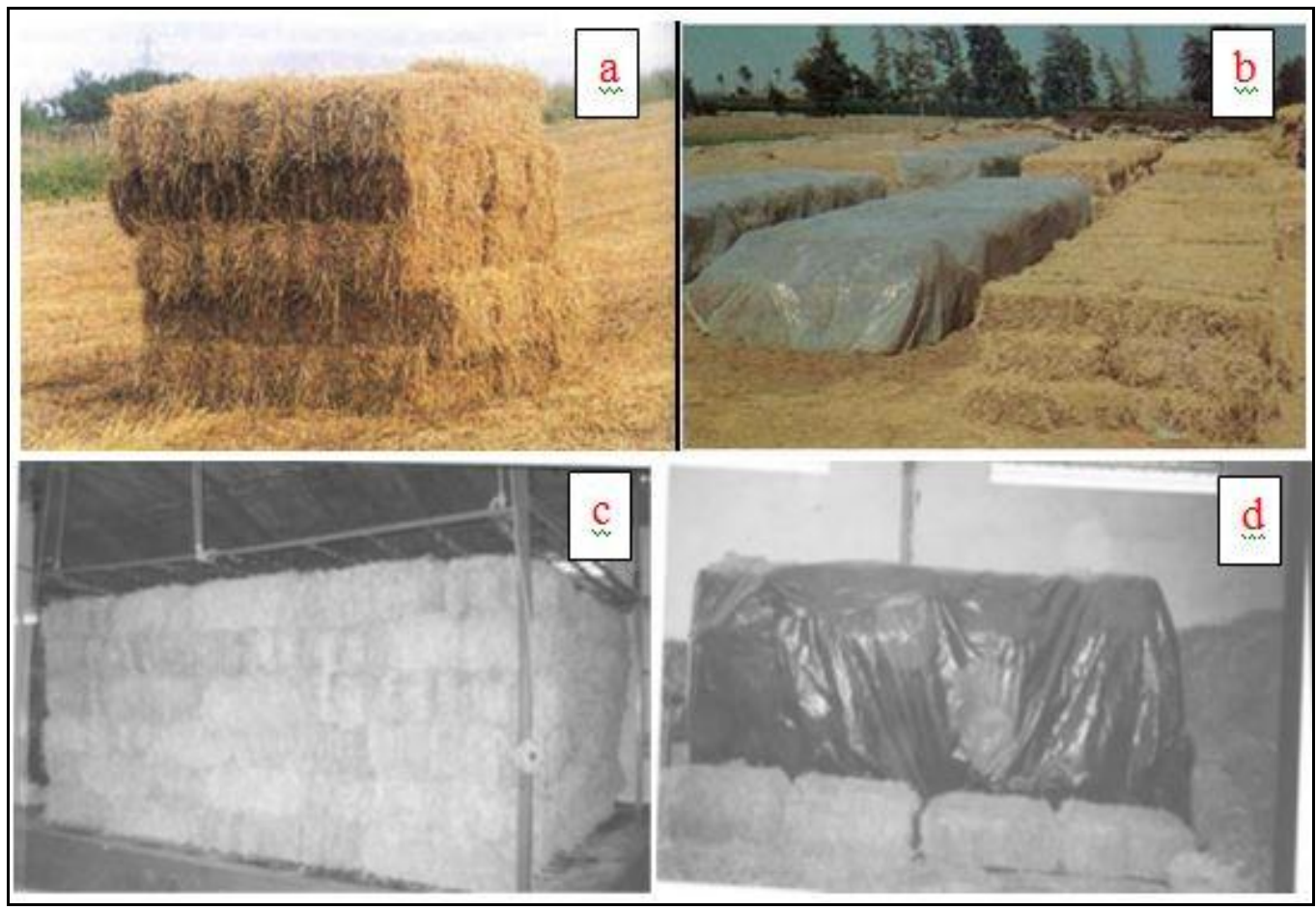


Table.1 Chemical/material used for fortification by various researchers

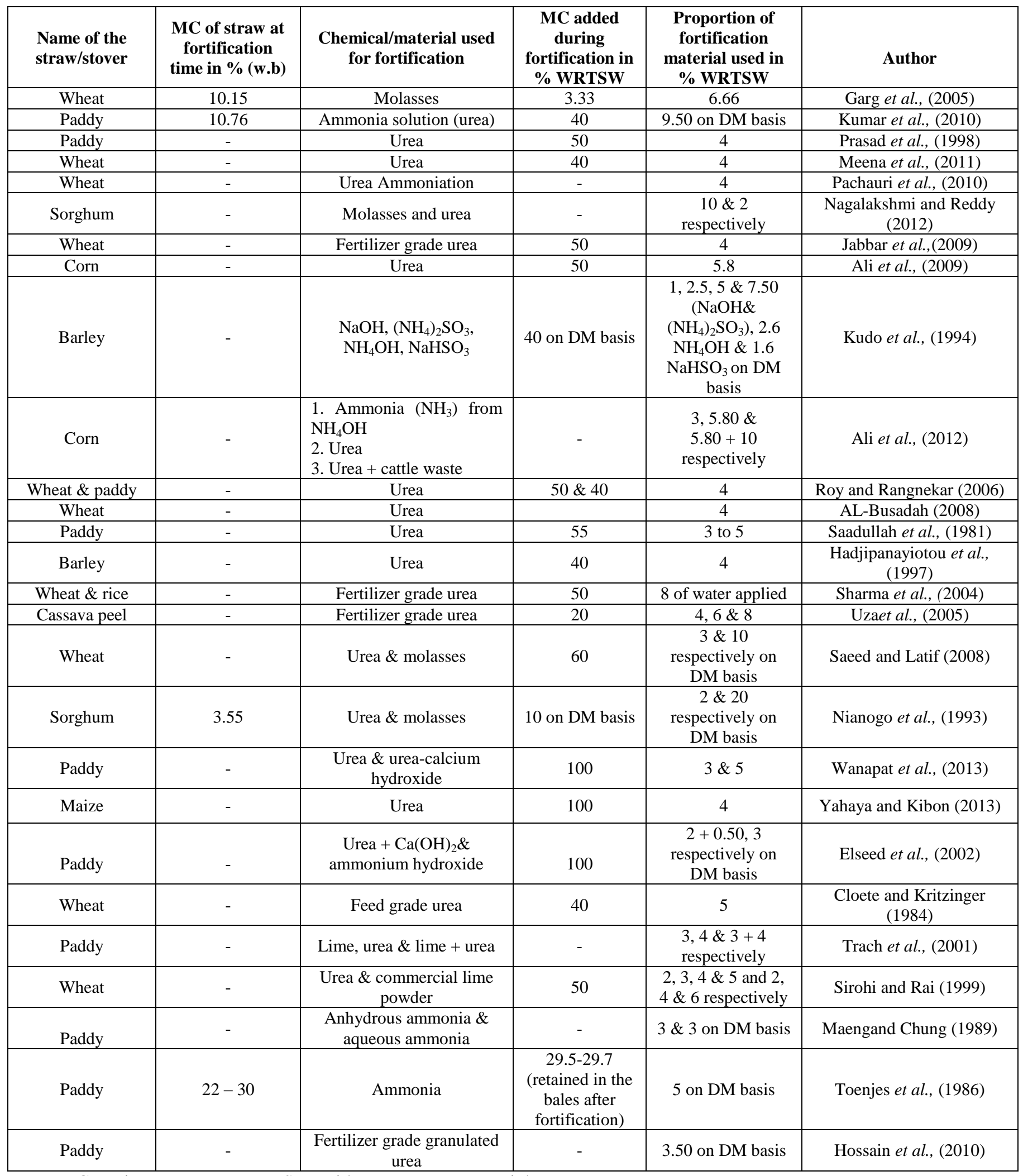

MC: moisture content; WRTSW: with respect to straw weight 


\section{Chemical treatment method for straw fortification}

The two types of chemical treatment methods are being practice in India for straw fortification. One among these is fortification of loose straw near to dairy barn or cowshed and other one fortification of baled straw in treatment plant. The loose straw fortification method (shown through schematic flow chart in Fig. 1) involves collection of straw from the field manually and transporting the collected straw near to the cowshed (Roy and Rangnekar, 2006). The straw will be chopped (if straw is not obtained from combine harvested field) and spread on the clean and hygienic floor near to cowshed or dairy barn. The required amount of fortification chemical will be weighed based on the dry matter (DM) content of the straw, mixing it with desired amount water and spraying the fortification solution on to the spread straw layer by layer by using garden sprayer as shown in figure 3 . The sprayed straw will be mixed thoroughly in order to ensure uniformity of spraying (Saadullah et al., 1981, Sharma et al., 2004, Ali et al., 2009 and Hossain et al., 2010). The fortified straw will be incubated for some specified days under the cover of plastic sheet or mud plaster (Jabbar et al., 2009). In this fortification method, the steps involved are collection of straw from the field, transporting the collected straw near to the cowshed or barn, preparation of urea solution, sprinkling of solution on straw and pressing the straw during treatment process. Thus requires more number of labours and also more time to fortify per unit weight of straw.

The second method of straw fortification involves baling of straw in the field, carrying the bales from field to treatment plant (as shown in figure 2 through a schematic flow chart). In treatment plant, the bales will be placed in the form of stacking one above the other up to a three to four bale height as shown in figure 4 . The pre calculated amount (on straw DM basis) of fortification chemical will dissolve with the known quantity of water to form a solution. Then the fortification solution is sprayed or dripped on the stack of bales in plant with the help of sprayer or dripper (Cloete and Kritzinger, 1984, Belanger et al., 1987, Kumar et al., 2010 and Ali et al., 2012). After fortification, the fortified bales may remained on the treatment plant for an hour in order to drain the excess flow of fortification solution from the bales before it get shifted to incubating place (Kumar et al., 2010). This method fortification is well suited for large scale whereas loose straw fortification method is suited for small scale requirements. This method is better as compare to first method in terms of saving time and labour expenses. But still it requires considerable number of labour for loading and unloading bales to and from the plant, aligning the dripping or spraying system to the stacks of bales in plant and covering the treated bales off-side the plant (Kumar et al., 2010). Because of these reasons, the total cost of fortification per unit weight of straw will increase.

\section{Limitations for adoption of straw fortification methods}

Various factors contributed to the lack of impact, most notably the difficulty by farmers to carry out the technical job unaided and the extra work of treatment. The lack of demonstration of satisfactory cost-benefit ratio of using urea treated straw during the entire production cycle of the animals also the reason for the unpopularity of straw fortification (Sharma et al., 2004). In the traditional fortification methods, the fortification of straw will be done in number of steps. Because of this, the traditional fortification methods become more time consuming and labour intensive process. 
In India, at present, the practice of straw fortification is done in two different methods. One of these methods is spraying of fortification solution (water + fortification chemicals with recommended proportion) on to the sun dried chopped straw, layer by layer. Another method is spraying of fortification solution on to an each layer of stack of straw bales. It clearly tells that the baling and fortification operation are being done separately and non-homogeneity of fortification within the bales. To reduce the number of operation i.e., baling operation and later fortification process, a simultaneous fortification cum baling operation in in-field condition is needed. So that the separate process of bales or straw fortification can be eliminated and which results in saving of time and labor expenses leading to cost for fortification.

\section{References}

AL-Busadah, K. A., 2008, Effects of feeding urea on milk composition in lactating goats. Scient. J. King Faisal Univ., 9 (2): 125-130.

Alhadhrami, 1991, Effect of preservatives and maturity on the nutritional value of alfalfa hay for lactating dairy cows. Unpublished Ph. D. Thesis, Univ. Arizona.

Ali, I., Fontenot, J. P. and Allen, V. G., 2009, Palatability and dry matter intake by sheep fed corn stover treated with different nitrogen sources. Pak. Vet. J., 29 (4): 199-201.

Ali, I., Fontenot, J. P. and Allen, V. G., 2012, Effects of feeding corn stover treated with different nitrogen sources on palatability and dry matter intake in sheep. J. Vet. Anim. Sci., 2 (1): 11-15.

Anonymous, 2013, Annu. Rep. 2011-12. Dept. animal husbandry, dairying \& fisheries, Ministry of agriculture, Govt. India, New Delhi, pp 1-8.
Anonymous, 2015, Cash crop, clamour for food cause fodder shortage. Deccan Herald, Friday, January 2, 2015, p. 13.

Belanger, G., St-Laurent, A. M., Esau, C. A., Nicholson, J. W. G. and Mcqueen, R. E., 1987, Urea for the preservation of moist hay in big round bales.Can. J. Anim. Sci., 67: 1043-1053.

Cloete, S.W.P., and Kritzinger, N. M., 1984, Urea ammoniation compared to urea supplementation as a method of improving the nutritive value of wheat straw for sheep. S. Afr. Anim. Sci., 14 (2): 59 - 63.

Elseed, A.M.A.F., Sekine, J., Hishinuma, M. and Hamana, K., 2002, Effects of ammonia, urea plus calcium hydroxide and animal urine treatments on chemical composition and in sacco degradability of rice straw. Asian-Asut. J. Anim. Sci., 16 (3): 368-373.

Garg, M.K., Lohan, O. P. and Jain, S., 2005, Development of wheat straw fortification machine.J. Agric. Eng., 42 (1): $27-30$

Ghate, S.R., and Bilanski, W. K., 1979, treating high-moisture alfalfa with urea. Trans. ASAE., 22 (3): 504-506.

Hadjipanayiotou, M., Economides, S., Kyprianou, G., Antoniou, I. and Photiou, A., 1997, Feeding urea treated barley straw to growing Friesian heifers. Livestock Res. Rural Dev., 9 (4): 1-11.

Hanafi, E. M., Khadrawy, H. H. E., Ahmed, W. M. and Zaabal, M. M., 2012, some observations on rice straw with emphasis on updates of its management. World Applied Sci. J., 16 (3): 354-361.

Hossain, M.M., Khan, M. J. and Akba, M. A., 2010, Nutrient digestibility and growth of local bull calves as affected by feeding urea and urease enzyme sources treated rice straw. Bang. J. Anim. Sci., 39 (1\&2): 97 - 105.

Jabbar, M.A., Muzafar, H., Khattak, F. M., Pasha, T. N. and Khalique, A., 2009, 
Simplification of urea treatment method of wheat straw for its better adoption by the farmers.S. Afri. J. Anim. Sci., 39 (1): 58-61.

Kudo, H., Cheng, K.J., Rode, L.M., Abdullah, N., Ho, Y. W., Hussain, H. Y. and Jalaludin, S., 1994, Effect of chemical treatment of barley straw on leaching and digestibility by rumen fluid and cellulolytic bacteria. AJAS, 7 (3): 389 396.

Kumar, U., Thakur, T.C. and Jaiswal, R.S., 2010, Ammoniation of baled paddy straw on ammonia (Urea) treatment plant.Indian J. Anim. Nutr., 27(1): 1-9.

Liu, J., Orskov, E. R. and Chen, X. B., 1990, Optimization steam treatment as a method for upgrading rice straw as feeds. Anim. feed Sci. Technol., 76: 345357.

Maeng, W.J., and Chung, T. Y., 1989, Nutritive value and growth response of cattle feed ammonia treated rice straw. AJAS, 2 (1): 1-6.

Mahesh, M.S., and Mohini, M., 2013, Biological treatment of crop residues for ruminants feeding: A review. Afr. $J$. Biotechnol., 12 (27): 4221-4231.

Makkar, H. P. S., 2000, Development and field evaluation of animal feed supplementation packages. Final reviews meet, IAEA technical cooperation regional AFRA project, Cairo, Egypt, 25-29 Nov., 2000.

Meena, J. P., Gupta, L., Tiwari, G. S. and Rajeev, G., 2011, Effect of feeding probiotic mixture with untreated or urea treated wheat straw on nutrient utilization in growing crossbred males. Indian J. Anim. Nutr., 28 (1): 39-43.

Mir, Z., Jan, E. Z., Robertson, J. A., McCartney, D. H. and Mir, P. S., 1991, Effects of ammoniation of brome-alfalfa and alfalfa hay stored as large round bales on preservation and feed quality. Can. J. Anim. Sci., 71: 755-765.
Nagalakshmi, D., and Reddy, D. N., 2012, Effect of feeding sorghum stover based densified blocks on nutrient utilization and rumen fermentation pattern in sheep. Indian J. Anim. Nutr., 29 (3): 262-267.

Nianogo, A. J., Louis, S. L., Solaiman, S., Ouedraogo, C. L. and Siaway, A., 1993, Effect of urea treatment on digestibility and utilization of sorghum straw. Biotechnol. Agron. Soc. Environ., 3 (2): 78-85.

Pachauri, S. K., Singh, S. K. and Mudgal, V., 2010, Effect of feeding wheat straw and urea ammoniated wheat straw based total mixed rations on the performance of female crossbred calves. Indian $J$. Anim. Nutr., 27 (1): 73-76.

Prasad, R. D. D., Reddy, M. R. and Reddy, G. V. N., 1998, Effect of feeding baled and stacked urea treated rice straw on the performance of crossbreed cows. Anim. feed Sci. Techno., 73: 347-352.

Roy, S., and Rangnekar, D. V., 2006, Farmer adoption of urea treatment of cereal straws for feeding of dairy animals: a success in Mithilamilkshed, India. Livestock Res. Rural Dev., 18 (8): 1-8.

Saadullah, M., Haque, M. and Dolberg, F., 1981, Effectiveness of ammonification through urea in improving the feeding value of rice straw in ruminants. Trop. Anim. Prod., 6 (1): 30-36.

Saeed, A. A., and Latif, F. A., 2008, Effect of time of ensiling on the nutritive value of wheat straw treated with urea and molasses. Alquadisia J. Vet. Med., 7 (2): $1-7$.

Sharma, K., Dutta, N. and Naulia, U., 2004, an on-farm appraisal of feeding ureatreated straw to buffaloes during late pregnancy and lactation in a mixed farming system. Livestock Res. Rural Dev., 16 (11): 1-8.

Sirohi, S. K., and Rai, S. N., 1999, Synergistic effect of urea and lime treatment of 
wheat straw on chemical composition, in saccoand in vitro digestibility. AsianAus. J. Anim. Sci., 12 (7): 1049-1053.

Smith, T., 2001, On-farm treatment of straws and stovers with urea. Univ. Reading, Reading, United Kingdom, 15-22.

Sultana, N., Hossain, S. M. J. and Hassan, M. R., 2011, Effect of frequent oil treatment on the performance of native growing rams under intensive management system. The Bangl, Veterinarian, 28 (1): 19-30.

Thakur, T. C., Jaiswal, R. S. and Verma, M. L., 2007, Management of crop residues after combining and its utilization as livestock feed under Indian conditions. Trans. ASABE, 16: 1-7.

Toenjes, D. A., Bell, M. and Jenkins, B., 1986, Baler ammoniation of rice straw. Calif. Agric., May-June, 15-17.

Trach, N. X., Mo, M. and Danet, C. X., 2001, Effects of treatment of rice straw with lime and/or urea on responses of growing cattle. Livestock Res. Rural Dev., 13 (5): 125-130.
Uza, D. V., Barde, R. E. and Ayoade, J. A., 2005, the effect of urea treated cassava peels as supplement to West African dwarf (wad) goats grazing natural pasture. Nigeria Vet. J., 26 (1): 1-9.

Walli, T. K., Gupta, B. N., Rai, S. N. and Singh, K., 1988, Biological treatment of straws, N-transactions during fermentation and subsequent utilization by ruminants. Fibrous crop residues as animal feed, Proce. Int. Workshop, 2728 Oct., 1988, NDRI (SRS), Bangalore, India, pp.75-81.

Wanapat, M., Kang, S., Hankla, N. and Phesatcha, K., 2013, Effect of rice straw treatment on feed intake, rumen fermentation and milk production in lactating dairy cows. Afr. J. Agric. Res., 8 (17): $1677-1687$.

Yahaya, M. B., and Kibon, A., 2013, Effect of supplementation and voluntary feed intake in red sokoto goats offered a basal diet of treated maize stover. Int. J. Agric. Biosci., 2 (1): 30-34.

\section{How to cite this article:}

Shrinivasa, D.J. and Devanand Maski. 2017. Opportunities and Challenges for Straw Fortification for Livestock Feed: Scope for Mechanization. Int.J.Curr.Microbiol.App.Sci. 6(9): 1661-1670. doi: https://doi.org/10.20546/ijcmas.2017.609.204 